\title{
ANALISIS KEPUASAN SELF MONITORING BLOOD GLUCOSE DENGAN THE GLUCOSE MONITORING SATISFACTION SURVEY
}

\author{
Shanty Chloranyta \\ Akademi Perawat Panca Bhakti Bandar Lampung, Indonesia \\ E-mail: shanty@pancabhakti.ac.id
}

\begin{abstract}
Abstrak
Kepuasan self monitoring blood glucose merupakan faktor penting dalam meningkatkan diabetes outcome pasien diabetes tipe 2. Penerapan evidence based nursing bertujuan mengidentifikasi kepuasan self monitoring blood glucose pada pasien diabetes tipe 2. Metode perumusan masalah yang digunakan dengan pendekatan problem $(\mathrm{P})$ intervention $(\mathrm{I})$ comparison $(\mathrm{C})$ outcome $(\mathrm{O})$, dan penelusuran literatur dengan sampel penelitian 51 pasien diabetes tipe 2 Alat ukur yang digunakan the glucose monitoring satisfaction survey (GMSS). Analisis menunjukkan rerata responden dalam penelitian ini $65 \%$ responden dengan total skor 49.4.Kesimpulan the glucose monitoring satisfaction surveydapat diterapkan.
\end{abstract}

Kata kunci: diabetes tipe 2; kepuasan self monitoring blood glucose; GMSS

\begin{abstract}
The satisfaction self monitoring of blood glucose is an important factor in improving diabetes outcomes type 2 diabetes patients. The application of evidence based nursing aims to identify the satisfaction self monitoring of blood glucose in type 2 diabetes patients. Problem formulation method used by the problem approach $(P)$ intervention $(I)$ comparison $(C)$ outcome $(O)$, and literature search with a sample of 51 type 2 diabetes patients. The measuring instrument used is the glucose monitoring satisfaction survey (GMSS). Analysis shows the average of respondents in this study was 65\% of respondents with a total score of 49.43. The glucose monitoring satisfaction survey conclusion can be applied.
\end{abstract}

Keyword: type 2 diabetic; satisfaction self monitoring blood glucose; GMSS

Dikirim: 22 Februari 2020

Diterima: 10 April 2020

Terbit: 20 April 2020 


\section{PENDAHULUAN}

Diabetes outcome yang baik pada diabetes akan meningkatkan kepuasan pasien. Kepuasan pasien juga akan mempengaruhi kepatuhan pasien terhadap pengelolaan diabetes serta untuk melakukan kontrol rutin (Doubova et al., 2009). Penelitian cross sectional yang dilakukan pada 6.671 pasien diabetes di Brazil menunjukkan bahwa kepuasan pasien dalam pengelolaan diabetes memiliki peran penting dalam meningkatkan diabetes outcome. Hasil penelitian menunjukkan bahwa pasien yang puas terhadap hasil pengelolaan diabetes memiliki diabetes outcome yang adekuat (Mendez et al., 2010).

Demikian halnya hasil systematic review yang dilakukan pada 52 artikel penelitian untuk mengkaji hasil dan komposisi dari manajemen pelayanan kesehatan dengan diabetes outcome berdasarkan kontrol rutin membuktikan bahwa sangat sedikit pasien yang melaporkan kepuasan sehingga mempengaruhi kunjungan pasien (Egginton et al., 2012).

Kepuasan merupakan indikator yang digunakan untuk mengevaluasi pelayanan kesehatan, mengidentifikasi perspektif pasien, meningkatkan aspek pelayanan. Selain itu, kepuasan pasien memberikan gambaran mengenai harapan dan preferensi pasien pada komponen dari proses perawatan, seperti akses, fasilitas yang tersedia, hubungan interpersonal dan kualitas teknis (Doubova et al., 2009). Hasil penelitian cross sectional yang dilakukan pada 17.246 sampel penelitian yang berusia 17 sampai dengan 30 tahun menunjukkan terdapat hubungan yang signifikan antara kepuasan hidup dan perubahan tingkah laku (Grant, Wardle, \& Steptoe, 2009).

Kepuasan pasien juga mempengaruhi kepatuhan pasien terhadap pengelolaan terapi, kontrol rutin (Doubova et al., 2009). Kepuasan pasien meningkatkan loyalitas pasien untuk merubah perilaku yang mendukung dalam perawatan pasien(Naidu, 2009).

Hasil penelitian cross sectional untuk menilai hubungan depresi dan kepuasan pengelolaan diabetes pada pasien diabetes menunjukkan depresi signifikan dengan kepuasan pasien. Pasien yang depresi, mengalami penurunan kepuasan (Bassett, Adelman, Gabbay, \& Tiangco, 2012). Hasil systematic review pada 24 artikel membuktikan kualitas pelayanan kesehatan signifikan mempengaruhi kepuasan pasien. Kepuasan pasien mempengaruhi tingkah laku pasien seperti loyalitas(Naidu, 2009). 
Demikian halnya, hasil penelitian Model of Integrated Ambulatory Care for patients with type 2 diabetes and/or hypertension (MIAC) study dilakukan pada 1.323 pasien membuktikan pasien puas terhadap pelayanan kesehatan. Dokter keluarga yang ramah, memberikan pendapat terhadap pilihan pengobatan, memberikan waktu yang lama untuk berdiskusi, kebersihan klinik, kemudahan prosedur administrasi mempengaruhi kepuasan pasien (Doubova et al., 2009).

Dikaitkan dengan hasil penelitian kualitatif untuk menjelaskan persepsi dan fungsi SMBG. SMBG pada orang diabetes tipe 2 akan dilakukan apabila pasien merasa puas dapat mencapai kadar glukosa darah sesuai dengan target yang ditentukan.(Brackney, 2010). Demikian halnya, penelitian cross sectional yang dilakukan pada 6.671 pasien diabetes di Brazil menunjukkan bahwa pasien yang puas terhadap hasil pengelolaan diabetes memiliki diabetes outcome yang adekuat (Mendez et al., 2010).

Elemen yang diukur dalam kepuasan pasien melakukan SMBG meliputi keterbukaan, pengaruh emosional, perilaku yang ditampilkan yang dipengaruhi oleh hasil pengukuran kadar glukosa darah dan manfaat mengukur kadar glukosa darah. Keterbukaan memberikan gambaran dampak yang menguntungkan dari penggunaan pengukuran kadar glukosa darah. Pengaruh emosional merupakan dampak negatif dari hasil pengukuran darah pada kualitas hidup.Perilaku yang ditampilkan akibat monitoring glukosa darah menjelaskan kesulitan pasien saat melakukan pemantauan glukosa darah. Manfaat menjelaskan keuntungan yang dirasakan setelah melakukan monitoring glukosa darah (Polonsky, Fisher, Hessler, \& Edelman, 2015).

\section{METODOLOGI}

Perumusan masalah klinis yang dilakukan dengan pendekatan PICO (Problem, Intervention, Comparison, Outcome). Problem yakni kepuasan, self monitoring blood glucose, diabetes tipe 2. Intervention format identifikasi kepuasan self monitoring blood glucose.Outcome yakni identifikasi kepuasan self monitoring blood glucose ditemukan Blood Glucose Monitoring System (BGMS), SelfMonitoring of Blood Glucose Obstacles Scale, Blood Glucose Monitoring System Rating Questionnaire Measurement Questionnaire (BGMSRQ), dan The Glucose Monitoring Satisfacion Survey (GMSS) (Polonsky et al., 2015).

Penerapan identifikasi kepuasan self monitoring blood glucose dengan kriteria 
inklusi yaitu klien diabetes tipe 2 ditunjukkan dengan rekam medis pasien dan data yang didapatkan dari kesekretariatan Persadia Bandar Lampung, responden yang melaksanakan SMBG minimal selama 1 tahun, didapatkan dari informasi dokter spesialis penyakit dalam dan perawat poliklinik Rumah Sakit Abdoel Moeloek Bandar Lampung, serta kesekretariatan Persadia Bandar Lampung, dapat berkomunikasi dengan baik, mampu membaca dan menulis dengan bahasa Indonesia, bersedia menjadi responden dalam penelitian. Penelitian dilakukan pada Bulan Maret 2017.

Adapun kriteria eksklusi dalam penelitian ini tidak mengalami kecacatan fisik (tunanetra, tunadaksa), tidak mengalami depresi dibuktikan dengan screening untuk mengukur depresi dengan menggunakan kuesioner CES-D (Roy et al., 2012), tidak melakukan pengobatan alternatif dan komplementer. Berdasarkan kriteria inklusi dan eksklusi yang ditetapkan total responden dalam penerapan EBN ini adalah 51 orang.

\section{HASIL}

Hasil penerapan identifikasi pengkajian kepuasan SMBG terhadap 51 pasien diabetes tipe 2 adalah sebagai berikut:
Tabel 1 Distribusi responden pasien diabetes tipe 2 di RSAM dan Persadia Bandar Lampung tahun $2017(n=51)$

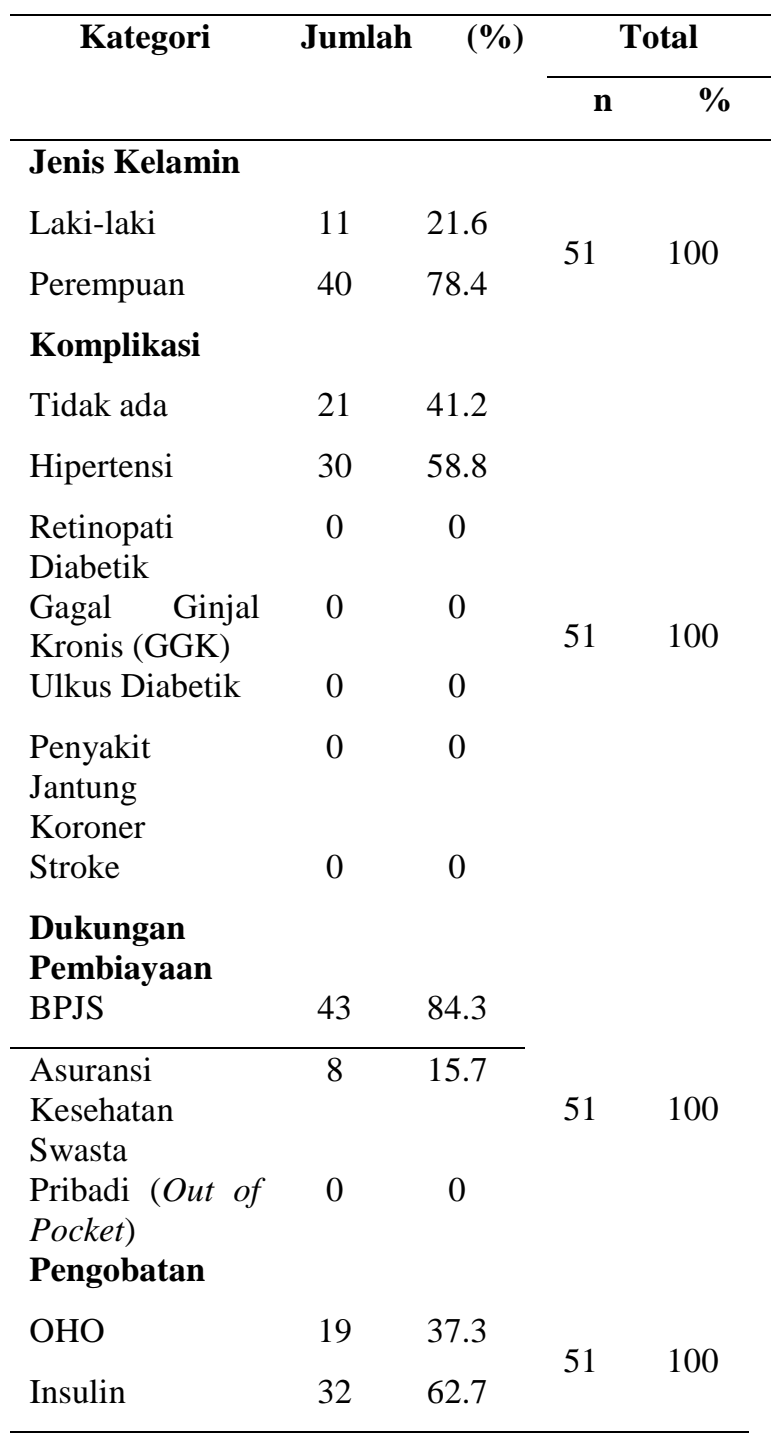

Tabel 1 menunjukkan karakteristik responden berdasarkan jenis kelamin menunjukkan pesentase terbanyak dengan perempuan sebanyak 40 responden (78.4 $\%$ ), komplikasi hipertensi 30 responden (58.8 \%), dukungan pembiayaan menggunakan BPJS 43 responden (84.3 $\%)$, pengobatan menggunakan insulin 32 responden $(62.7 \%)$. 
Tabel 2. Distribusi responden berdasarkan usia dan kepuasan SMBG pasien diabetes tipe 2 di RSAM dan Persadia Bandar Lampung tahun $2017(n=51)$

\begin{tabular}{lcccc}
\hline Variabel & Mean \pm SD & Median & $\begin{array}{c}\text { Min- } \\
\text { Maks }\end{array}$ & $\begin{array}{c}95 \% \\
\text { CI }\end{array}$ \\
\hline Usia & $50.73 \pm 3.47$ & 51 & $45-58$ & $\begin{array}{c}49.75- \\
51.70\end{array}$ \\
$\begin{array}{l}\text { Kepuasan } \\
\text { SMBG }\end{array}$ & $49.43 \pm 6.62$ & 50 & $35-65$ & $\begin{array}{c}47.57- \\
51.29\end{array}$ \\
\hline
\end{tabular}

Tabel 2 menunjukkan rerata usia responden diabetes tipe 2 yakni 50.71 tahun dengan standar deviasi 3.47. Selain itu, diyakini 95\% rata-rata usia responden berada antara 49.75 tahun hingga 51.70 tahun. Kepuasan SMBG menunjukkan rerata 49.43 dengan standar deviasi 6.62.Hal ini menunjukkan $65 \%$ responden dalam penelitian ini memiliki total skor 49.43 dari 51 responden.Selain itu juga diyakini $95 \%$ rerata kepuasan SMBG antara 47.57 hingga 51.29.

\section{PEMBAHASAN}

Hasil analisis menunjukkan rerata umur pasien diabetes tipe adalah 50.73 tahun. Usia 50.73 tahun berdasarkan WHO merupakan usia pada tahap pertengahan (middle age). Hasil penelitian ini menunjukkanbahwa kemungkinan kejadian diabetes dalam penelitian ini disebabkan karena perubahan metabolismepada tubuh diakibatkan oleh proses penuaan. Usia yang bertambah meningkatkan perubahan pada komposisi lemak tubuh. Komposisi lemak subkutan menurun, sedangkan lemak pada organ visceral meningkat (lemak di dalam rongga perut). Peningkatan lemak pada organ visceral yang tidak proporsional dibandingkan dengan lemak subkutan menyebabkan distribusi lemak yang tidak merata (Barzilai, Huffman, Muzumdar, \& Bartke, 2012).

Selain itu, gangguan pada tubuh akibat proses penuaan yakni kelemahan dapat menyebabkan berkurangnya mobilitas sehingga terjadi pengurangan pengeluaran energi dan insulin. Penuaan dikaitkan dengan hilangnya fungsi mitokondria secara progresif dalam berbagai bentuk jaringan, termasuk otot rangka(Barzilai et al., 2012).

Beberapa penelitian menunjukkan kejadian diabetes berada pada rentang usia 45-58 tahun, seperti pada data kejadian diabetes menurut IDF (2015) berdasarkan tingkatan usia yakni semakin tua usia kejadian diabetes semakin tinggi. Kejadian diabetes pada rentang usia 40-49 tahun (11\%), 5059 tahun (16\%), 60-69 tahun (19.5\%) 7079 tahun (22 \%). Hasil penelitian yang sesuai dengan penelitian ini dilakukan pada 3.471 subyek penelitian di sebuah studi Offspring Farmingham untuk mengetahui prediksi variasi genetik dalam meningkatkan penyakit diabetes 
membuktikan 144 pasien diabetes berusia $<50$ tahun dan 302 pasien berusia $\geq 50$ tahun (Miguel-Yanes et al., 2011).

Demikian halnya dengan penelitian prospective cohort study untuk mengidentifikasi faktor resiko onset terjadinya diabetes menunjukkan dari 2.459 subjek penelitian dan 144 subjek penelitian yang mengalami diabetes berusia pada rentang 18-50 tahun, dan insidensi kejadian diabetes pada usia 40-50 tahun yaitu $3.4 \%$ per 1000 orang dalam setiap tahunnya. Peningkatan kejadian diabetes $8.6 \%$ pada usia $40-50$ tahun dan $7.7 \%$ meningkat pada usia 30-39 tahun (Nguyen et al., 2012). Kejadian diabetes di Indonesia berdasarkan data Riskesdas (2013) menunjukkan pada rentang usia 4555 tahun (3.3\%), 55-64 tahun (4.8\%), 65$74 \operatorname{tahun}(4.2 \%)$.

Hasil analisis menunjukkan persentase terbesar dengan jenis kelamin perempuan sebanyak 40 responden $(78.4 \%)$ dan 11 responden $(21.6 \%)$ berjenis kelamin lakilaki. Hasil penelitian ini menunjukkan kejadian diabetes terjadi lebih banyak pada perempuan dengan rerata usia 50.73 tahun karena sampel dalam penelitian ini lebih banyak perempuan, selain itu kemungkinan dapat disebabkan oleh perubahan hormonal yang terjadi akibat proses penuaan sehingga mengakibatkan resiko lebih tinggi terjadi diabetes pada perempuan dibandingkan dengan laki-laki.

Perempuan dengan diabetes tipe 2 mengalami perubahan hormonal akibat proses penuaan. Perubahan yang terjadi yaitu penurunan fungsi endokrin akibat proses penuaan. Perubahan pada sekresi growth hormon menurun seiring bertambahnya usia, mengakibatkan penurunan konsentrasi IGF-1 secara bersamaan (Barzilai et al., 2012).

Selain itu, faktor resiko yang berkontribusi pada perempuan dengan diabetes tipe 2 yakni perempuan memiliki BMI lebih tinggi dibandingkan dengan laki-laki. Hasil penelitian yang dilakukan oleh The Korea National Health and Nutrition Examination Survey sejak tahun 2007 sampai dengan 2010 pada 21.797 responden menunjukkan rerata body mass index $(\mathrm{BMI}) 26.1 \mathrm{~kg} / \mathrm{m}^{2}$ pada perempuan dan $25.0 \mathrm{~kg} / \mathrm{m}^{2}$ pda laki-laki (Kwon, 2014).

Penelitian lain yang sesuai dengan penelitian ini untuk menginvestigasi prevalensi dan insidensi kondisi geriatrik pada orang dewasa dan usia lanjut dengan diabetes menunjukkan 3.506 responden terbanyak perempuan yakni 1.811 responden (51.66 \%) (Cigolle et al., 2010). 
Berdasarkan beberapa penelitian menunjukkan prevalensi diabetes lebih tinggi pada perempuan dibandingkan dengan laki-laki, seperti pada penelitian cross sectional untuk menentukan prevalensi jenis kelamin dan usia yang berhubungan dengan faktor resiko diabetes di Nigeria. Hasil penelitian yang dilakukan pada 3.500 responden menunjukkan kejadian diabetes pada responden perempuan 1.968 (56.2\%) lebih banyak dibandingkan pada laki-laki yaitu 1.532 (43.8 \%) (Ekpenyong, Akpan, Ibu, \& Nyebuk, 2012).

Penelitian lainnya, juga menunjukkan bahwa kejadian diabetes pada perempuan lebih tinggi dibandingkan dengan laki-laki. Hasil penelitian yang dilakukan untuk menganalisa diabetes dan faktor resiko yang berhubungan dengan perempuan dan laki-laki pada 1.503 responden di India menunjukkan $16.7 \%$ diabetes tipe 2 berjenis kelamin perempuan dan $9.7 \%$ laki-laki (Scavini et al., 2003). Hasil penelitian lain yang juga sesuai dengan penelitian ini dilakukan di 18 rumah sakit dan pusat kesehatan di Jordania Selatan, Utara dan Tengah pada 1.079 responden menunjukkan $53 \%$ responden berjenis kelamin laki-laki dan $47 \%$ perempuan (Al-keilani, Almomani, Al-sawalha, \& Shhabat, 2017). Demikian halnya, menurut data diabetes di Indonesia berdasarkan data Riskesdas (2013) menunjukkan lebih tinggi pada perempuan dibandingkan pada laki-laki.Kejadian diabetes pada laki-laki $1.4 \%$ dan perempuan $1.7 \%$.

Berbeda halnya dengan penelitian prevalensi diabetes menurut data IDF (2015) berdasarkan jenis kelamin prevalensi diabetes lebih tinggi pada lakilaki dibandingkan dengan perempuan. Kelompok usia 40-49 tahun pada laki-laki lebih tinggi kejadian diabetes $11 \%$ dibandingkan perempuan yakni $8 \%$, dan usia 50-59 tahun diabetes laki-laki sekitar $16 \%$ dan perempuan yakni $13 \%$. Demikian halnya dengan penelitian cross sectional yang dilakukan di China dengan 1.545 pasien diabetes tipe 2 menunjukkan kejadian diabetes pada laki-laki $67.81 \%$ dan $32.2 \%$ perempuan (Yu et al., 2016).

Hasil analisis menunjukkan komplikasi terbanyak yaitu hipertensi pada 30 responden $(58.8 \%)$ dan tidak ada komplikasi 21 responden (41.2\%). Hipertensi merupakan salah satu penyakit kardiovaskuler (CVD) yang dapat terjadi pada pasien dengan diabetes. Resiko penyakit kardiovaskuler (CVD) pada diabetes diakibatkan oleh multifaktor yang kompleks. Aterosklerosis memiliki peran utama pada pasien diabetes yang disebabkan oleh dislipidemia dan 
perubahan pada struktur partikel lipoprotein plasma. Pasien diabetes 97\% mengalami dislipidemia dengan karakteristik terjadi peningkatan trigliserida dan penurunan kolesterol HDL (Dokken, 2008).

Selain itu, ditemukan kelainan struktur partikel lipoprotein pada plasma pasien dengan diabetes.Pada diabetes bentuk dominan dari LDL kecil dan padat.Partikel LDL yang kecil lebih aterogenik dari partikel LDL yang besar, karena dapat lebih mudah menembus dan membentuk lapisan kuat pada dinding arteri dan mudah teroksidasi. LDL yang teroksidasi merupakan proaterogenik, dan mengakibatkan perubahan, meliputi menarik leukosit ke intima, meningkatkan kemampuan leukosit untuk menelan lipid dan berdiferensiasi menjadi sel busa, dan merangsang proliferasi leukosit, endotel sel, dan sel-sel otot polos, sehingga terbentuk formasi plak aterosklerotik (Dokken, 2008).

LDL pada diabetes menjadi terglikasi sehingga memiliki waktu paruh yang panjang dan makin meningkatkan aterosklerosis, dan perubahan pada glikasi HDL menjadi lebih pendek waktu paruh sehingga HDL tidak dapat melindungi terhadap aterosklerosis. Hipertrigliserida juga terjadi pada diabetes karena kurangnya aksi insulin dalam mengatur fluks lipid. Insulin mengktikan enzim lipoprotein lipase, yang membantu lemak bebas masuk ke dalam jaringan adiposa dan menekan aktivitas enzim hormon lipase sehingga aliran asam lemak bebas turun pada sirkulasi. Kondisi hipertrigliserida menyebabkan peningkatan produksi bentuk padat LDL dan menurunkan HDL ke hati. Dislipidemia dan disfungsi endotel memberikan kontribusi terjadinya aterosklerosis (Dokken, 2008).

Faktor yang juga berkontribusi terhadap komplikasi pada diabetes yaitu lama menderita diabetes. Penelitian United Kingdom Prospective Diabetes Study (UKPDS) dari 5.102 partisipan setelah dilakukan follow up selama 25 tahun pasien mengalami komplikasi setelah didiagnosis diabetes. Hasil penelitian UPKDS membuktikan kematian pada 2.260 pasien, serangan miokard infark pertama 1.014 pasien, dan yang kedua 169 pasien, gagal jantung kongestif pada 351 pasien, serta ischemic heart disease 749 pasien. Gangguan yang terjadi pada pembuluh darah meningkatkan serangan stroke berulang.Serangan stroke pertama terjadi pada 504 pasien dan serangan stroke kedua 78 pasien. Komplikasi mikrovaskuler yang terjadi yaitu kebutaan 271 pasien, gagal ginjal 113 pasien, 
amputasi 171 dan ulkus 97 pasien (Hayes, Leal, Gray, Holman, \& Clarke, 2013).

Penelitian ini yang sesuai dengan penelitian ini, systematic review yang dilakukan untuk mengetahui prevalensi populasi dalam memanfaatkan strategi mengendalikan tekanan darah dan berat badan serta kadar glukosa darah. Hasil systematic review dari total 2.688 penelitian menujukkan 92 studi yang mengobservasi prevalensi hipertensi membuktikan hipertensi pada pasien diabetes merupakan kejadian yang tinggi di semua wilayah. Sebagian besar penelitian menunjukkan hipertensi $>50 \%$, dan bahkan > 75\%. Di kawasan Negara Asia $\geq 70 \%$, Eropa $>80 \%$, Amerika Utara dan Selatan > $30 \%$ (Colosia, Palencia, \& Khan, 2013).

Hasil analisis menunjukkan dukungan pembiayaanterbanyak menggunakan BPJS 43 responden $(84.3 \%)$ dan asuransi kesehatan $\quad$ swasta 8 responden $\quad(15.7$ \%).Penelitian dilakukan di RSAM Bandar Lampung, umumnya responden dalam penelitian ini menggunakan BPJS kesehatan karena rerata responden merupakan pegawai Negeri Sipil.BPJS memiliki 2 jenis produk yakni BPJS ketenagakerjaan dan BPJS kesehatan. BPJS Kesehatan diperuntukkan asuransi kesehatan, sebagai proteksi nasabah saat terjadi masalah kesehatan karena kecelakaan atau sakit dan harus melakukan upaya pengobatan, sedangkan BPJS ketenagakerjaan meliputi investasi yang menjadi tabungan dana pensiun dan asuransi kecelakaan yang banyak diperuntukkan bagi karyawan swasta.

Hasil penelitian menunjukkan $84.3 \%$ responden menggunakan BPJS dalam melakukan upaya perawatan kesehatan pada diabetes. BPJS merupakan salah satu kebijakan dalam kesehatan di Indonesia, memiliki badan hukum yang dibentuk untuk menyelenggarakan program jaminan sosial sesuai dengan Undang-Undang Dasar 1945, Undang-Undang Nomor 40 Tahun 2004 tentang Sistem Jaminan Sosial Nasional, Undang-Undang Nomor 24 Tahun 2011 tentang Badan Penyelenggara Jaminan Sosial (BPJS, 2014).

Diabetes membutuhkan perawatan dan pembiayaan yang rutin dan terus menerus.Perkiraan yang disampaikan IDF (2015) biaya yang dibutuhkan dalam perawatan diabetes sekitar 106 milyar sampai dengan 191 milyardan diperkirakan menghabiskan $10 \%$ dari total anggaran kesehatan dari setiap Negara.

Chronic Care Model (CCM) pada awalnya dikembangkan oleh Wagner pada tahun 1998 untuk meningkatkan perawatan pada 
pasien dengan kondisi kronis. Penelitian menunjukkan pada orang dengan penyakit kronis tidak menerima terapi yang efektif, kontrol terhadap penyakit yang buruk dan tidak puas dengan perawatan kesehatan mereka (Wagner, 1998).

CCM meningkatkan kualitas pelayanan pada kondisi kronis dengan mengidentifikasi elemen dasar dari sistem pelayanan kesehatan, sehingga interaksi antara pasien dan pemberi layanan kesehatan menjadi lebih produktif. Interaksi beberapa faktor yang berkaitan dengan CCM pada beberapa tingkatan, meliputi individu, keluarga, masyarakat dan kebijakan sosial ekonomi makro pada perspektif ekologi sosial (Baumann \& Dang, 2012).

Enam komponen $\mathrm{CCM}$ yaitu health system, self management support, decision support, delivery system design, clinical information systems, community resources and policies. Komponen CCM dapat meningkatkan keberhasilan pada pengelolaan diabetes. Hasil systematic review tentang $\mathrm{CCM}$ dan manajemen diabetes di US, menunjukkan penerapan CCM dalam perawatan primer AS pada pasien diabetes meningkatkan keberhasilan dalam manajemen diabetes di US (Stellefson, Dipnarine, \& Stopka, 2013).
Manajemen diabetes yang tepat dapat meminimalkan biaya pengeluaran terhadap pengelolaan diabetes dengan pendekatan CCM.Komponen CCM meliputi health system, self management support, decision support, delivery system design, clinical information systems, community resources and policies. Hasil systematic review tentang CCM dan manajemen diabetes di US, menunjukkan penerapan CCM dalam perawatan primer AS meningkatkan keberhasilan dalam manajemen diabetes di US. (Stellefson, Dipnarine, \& Stopka, 2013).

Kebijakan publik yang dikembangkan dan dirancang untuk meningkatkan kesehatan masyarakat, melibatkan partisipasi aktif terhadap kebijakan berdasarkan pada Undang-Undang dan Peraturan Perundangundangan yang berlaku.Pendekatan CCM menggabungkan pendekatan yang beragam serta saling melengkapi dan dapat dengan muda digunakan oleh individu, keluarga/masyarakat dan pemerintah. Hasil systematic review pada 7 artikel penelitian menetapkan strategi untuk menggunakan sumber daya masyarakat dan membentuk kebijakan publik. Kolaborasi antara berbagai pihak seperti kemitraan dapat memberikan akses lebih besar terhadap dana, sistem informasi, dan dukungan administratif untuk dalam penerapan CCM (Stellefson, Dipnarine, \& Stopka, 2013). 
Berdasarkan beberapa penelitian yang juga menunjukkan umumnya pasien diabetes menggunakan asuransi kesehatan, seperti pada penelitian dengan 1.079 responden penelitian menunjukkan pasien dengan diabetes yang menggunakan asuransi kesehatan 900 pasien $(92.0 \%)$ dan pasien yang tidak menggunakan asuransi kesehatan atau pribadi yakni 78 pasien (8\%) (Al-keilani et al., 2017).

Demikian halnya dengan penelitian yang dilakukan di Jerman sejak tahun 2009 sampai dengan 2010 menunjukkan jumlah pasien dengan diabetes sekitar 4.6 juta pada tahun 2009 dan 4,7 juta pada tahun 2010 (Tamayo et al., 2016). Penelitian lainnya, untuk menilai penggunaan pusat kesehatan oleh pasien diabetes tipe 2 di Jerman menunjukkan total biaya pengeluaran yang dibutuhkan oleh pasien diabetes tipe 2 berjumlah sekitar 33.3 miliar pada tahun 2010 (Muller et al., 2015).

Hasil analisis menunjukkan responden yang menggunakan insulin 32 responden $(62.7 \%)$ dan $\mathrm{OHO} \quad 19$ (37. 3 \%).Pengontrolan kadar glukosa darah dapat dilakukan dengan $\mathrm{OHO}$ dan insulin, yang diberikan bersama dengan pengaturan makan dan aktivitas fisik (Perkeni, 2015). Penggunaan insulin pada pasien diabetes dapat mengurangi risiko komplikasi pada diabetes yakni kematian (RR: 0.92, 95\% CI: 0.80-1.07), infark miokard (RR:1.07, 95\% CI: 0,90), stroke (RR:. 0.88，95\% CI: 0,59-1,32) serta amputasi (RR: 0.92, 95\% CI: 0,48-1,74), kebutaan (RR: 1.10, 95\% CI.. 0.76-1.60) atau gagal ginjal (RR: 0.68, 95\% CI: 0.431.06) (Erpeldinger et al., 2016).

Penelitian menunjukkan penggunaaan OHO efektif pada pasien diabetes, serta tidak menyebabkan hipoglikemia dibandingkan dengan insulin. Hasil penelitian meta analisis random control trial pada 1.632 artikel penelitian dan 18.599 sampel membuktikan obat hipoglikemia oral dibandingkan dengan insulin secara signifikan lebih rendah terjadinya resiko hipoglikemia (RR: 2.62 95\% CI:2.48-2.77) (Erpeldinger et al., 2016).

Penelitian yang sesuai dilakukan pada 1.079 responden dengan diabetes tipe 2 menunjukkan pasien yang menggunakan insulin yakni 193 (33.8 \%) lebih besar dibandingkan dengan pasien yang menggunakan $\mathrm{OHO}$ dengan melakukan diet dan/latihan fisik $65(11.4 \%)$ serta menggunakan insulin dan $\mathrm{OHO} 47$ (8.2\%) (Al-keilani et al., 2017). 
Hasil penelitian menunjukkan rerata responden dalam penelitian dengan median 28 dengan total skor terendah 0 dan skor tertinggi 48. Hal ini menunjukkan $58 \%$ responden dalam penelitian ini memiliki median skor diabetes self management yakni 28.

Hasil penelitian menunjukkan dari keempat item yang diukur dari keempat item penyataan. Item manajemen glukosa darah memiliki total nilai skor tertinggi, dan total nilai skor terendah pada item pernyataan kontrol terhadap diet. Hal ini menunjukkan responden dalam penelitian ini melakukan manajemen glukosa darah secara rutin dengan SMBG, akan tetapi responden tidak patuh terhadap kontrol diet.

Komponen pendekatan CCM yakni self management support membantu pasien untuk berperan aktif dalam perawatan diabetes secara mandiri untuk mencapai outcome sesuai dengan yang diharapkan (Siminerio, Zgibor, \& Jr, 2004). Pemberdayaaan dan persiapan pasien untuk mengelola kesehatan dan perawatan kesehatan dengan menekankan peran sentral pasien dalam mengelola kesehatan, menggunakan strategi dukungan manajemen mandiri yang efektif yang mencakup penilaian, penetapan tujuan, perencanaan tindakan, pemecahan masalah dan tindak lanjut serta mengatur sumber daya internal dan masyarakat untuk memberikan dukungan manajemen mandiri kepada pasien.

Pendekatan CCM meningkatkan peran dan keterlibatan pasien dalam mengambil keputusan yang dapat mempengaruhi self management dengan upaya pendekatan kolaboratif, penyedia layanan dan pasien bekerja sama untuk menentukan masalah, menetapkan prioritas, menetapkan tujuan, membuat rencana pengobatan dan memecahkan masalah di sepanjang jalan (Stellefson, Dipnarine, \& Stopka, 2013).

Hasil systematic review dan meta analisis pada 184 artikel penelitian menunjukkan self management signifikan meningkatkan diabetes outcome. Upaya keterlibatan pasien pada kondisi kronis yang membutuhkan pengelolaan yang sangat lama dapat ditingkatkan dengan intervensi self management. Self management juga dapat meningkatkan efisiensi penggunaan dari pelayanan kesehatanseperti pelayanan kesehatan primer atau rumah sakit (Panagioti et al., 2014). Demikian halnya dengan systematic review menunjukkan diabetes self management pada pasien diabetes memiliki peranan penting dalam mencapai outcome yang diharapkan (Heinrich, Schaper, \& Vries, 2010). 
Hasil penelitian menunjukkan rerata responden dalam penelitian ini dengan rerata total skor 49.43 dari total skor tertinggi kepuasan SMBG 75. Hal ini menunjukkan $65 \%$ responden dalam penelitian ini memiliki total skor 49.43 dari 51 responden.Kepuasan yang dimaksud dalam penelitian ini menggambarkan harapan pasien setelah melakukan self monitoring blood glucose meliputi keterbukaan, pengaruh emosional, perilaku dan manfaat dari monitoring glukosa darah yang diukur dengan menggunakan alat ukur GMSS (Polonsky et al., 2015).

Kepuasan SMBG responden dalam penelitian ini menunjukkan dari keempat item yang diukur item manfaat memiliki total nilai skor terendah dan total nilai skor tertinggi adalah perilaku. Hal ini menunjukkan responden dalam penelitian melakukan perubahan perilaku dalam SMBG sehingga hasil pengukuran diabetes outcome sesuai dengan harapan dari pasien sehingga pasien merasa puas, tidak khawatir dan pasien mendapatkan manfaat dari pemeriksaan diabetes outcome untuk menentukan diabetes self management yang tepat serta kualitas hidup semakin baik.

Hasil penelitian ini sesuai oleh penelitian yang dilakukan di UK pada pasien diabetes type 2 yang melakukan SMBG pada 554 responden diabetes tipe 2 menunjukkan $80 \%$ responden melaporkan kepuasan dalam melakukan SMBG. Responden menyatakan merasa diabetes dapat terkontrol dengan melakukan SMBG (Barnard, Young, \& Waugh, 2010).

Demikian halnya dengan hasil penelitian kualitatif menjelaskan persepsi dan fungsi dalam melakukan SMBG pada diabetes tipe 2, pasien akan melakukan SMBG apabila pasien merasa puas dapat mencapai kadar glukosa darah sesuai dengan target yang ditentukan(Brackney, 2010). Demikian halnya, penelitian cross sectional yang dilakukan pada 6.671 pasien diabetes di Brazil menunjukkan bahwa pasien yang puas terhadap hasil pengelolaan diabetes memiliki diabetes outcome yang adekuat (Mendez et al., 2010). Diabetes outcome yang adekuat akan meningkatkan kepuasan pasien dan mempengaruhi kepatuhan pasien terhadap pengelolaan diabetes (Doubova et al., 2009).

Hambatan pada penerapan identifikasi kepuasan SMBG ini terdapat kondisi tertentupasien DM tidak dapat mengisi sendiri format GMSSseperti retinopati diabetik, waktuyang dibutuhkan untuk mengisi kuesioner kurang lebih selama 1015 menit sehingga pasien tidak fokus 
karena takut dipanggil oleh dokter untuk dilakukan pemeriksaan

\section{KESIMPULAN}

Kesimpulan dari hasil penelitian ini yakni instrument GMSS dapat digunakan, responden dapat mengisi kuesioner dengan mudah, paham dan dapat menjawab kuesioner dengan tepat, perawat dan tenaga kesehatan dapat mudah menentukan tingkat kepuasan self monitoring blood glucose dengan GMSS.

\section{KEPUSTAKAAN}

Al-keilani, M. S., Almomani, B. A., Alsawalha, N. A., \& Shhabat, B. A. (2017). Self monitoring of blood glucose among patients with diabetes in Jordan: perception, adherence, and influential factors. Diabetes Research and Clinical Practice. http://doi.org/10.1016/j.diabres.2017. 01.005

Barnard, K. D., Young, A. J., \& Waugh, N. R. (2010).Self monitoring of blood glucose - a survey of diabetes UK members with type 2 diabetes who use SMBG.BMC Research Notes, 3(1), 318 .

Bassett, J., Adelman, A., Gabbay, R., \& Tiangco, R. M. A. (2012). Relationship between depression and treatment satisfaction among patients with type 2 diabetes. Journal Diabetes Metabolic, 3(7). http://doi.org/10.4172/2155-

$\underline{6156.1000210}$

Barzilai, N., Huffman, D. M., Muzumdar, R. H., \& Bartke, A. (2012). The critical role of metabolic pathways in aging. Diabetes, 61, 1315-1322. http://doi.org/10.2337/db11-1300

Baumann, L. C., \& Dang, T. T. N. (2012). HElping patients with chronic conditions overcome barriers to self care. The Nurse Practioner, 37(3), $32-38$.

Brackney, D. E. (2010). “ Knowing where $i$ am at ": The experience of self monitoring blood glucose for people with non insulin requiring type 2 diabetes. Dissertation.

Cigolle, C. T., Lee, P. G., Langa, K. M., Lee, Y., Tian, Z., \& Blaum, C. S. (2010). Geriatric conditions develop in middle aged adults with diabetes. Journal General Internal Medicine, 26(3), 272-279. http://doi.org/10.1007/s11606-010$1510-\mathrm{y}$

Colosia, A. D., Palencia, R., \& Khan, S. (2013). Prevalence of hypertension and obesity in patients with type 2 diabetes mellitus in observational studies: a systematic literature review. Diabetes, Metabolic 
Syndrome and Obesity: Targets and Therapy, 6, 327-338. http://doi.org/10.2147/DSMO.S51325

Dokken, B. B. (2008). The pathophysiology of cardiovascular disease and diabetes: beyond blood pressure and lipids. Diabetes Research and Clinical Practice, 21(3), 160-165.

Doubova, S. V., Pérez-cuevas, R., ZepedeArias, M., \& Flores-Hernandez, S. (2009). Satisfaction of patients suffering from type 2 diabetes and / or hypertension with care offered in family medicine clinics in Mexico, 51(3), 231-219.

Egginton, J. S., Ridgeway, J. L., Shah, N. D., Balasubramaniam, S., Emmanuel, J. R., Prokop, L. J., ... Murad, M. H. (2012). Care management for Type 2 diabetes in the United States: a systematic review and meta-analysis. Journal BMC Health Services Research, 12(72). http://doi.org/10.1186/1472-6963-12$\underline{72}$

Ekpenyong, C. E., Akpan, U. P., Ibu, J. O., \& Nyebuk, D. E. (2012). Gender and age specific prevalence and associated risk factors of type 2 diabetes mellitus in Uyo Metropolis South Eastern Nigeria. Diabetologia Croatica, 17-28.
Erpeldinger, S., Rehman, M. B., Berkhout, C., Pigache, C., Zerbib, Y., Regnault, F., ... Gueyffier, F. (2016). Efficacy and safety of insulin in type 2 diabetes: meta-analysis of randomised controlled trials. Journal BMC Endocrine Disorders, 16, 1-15. http://doi.org/10.1186/s12902-0160120-z

Grant, N., Wardle, J., \& Steptoe, A. (2009). The relationship between life satisfaction and health behavior: A Cross-cultural analysis of young adults. International Journal Behaviour Medicine, 16, 259-268. http://doi.org/10.1007/s12529-0099032-X

Hayes, A. J., Leal, J., Gray, A. M., Holman, R. R., \& Clarke, P. M. (2013). UKPDS outcomes model 2 : a new version of a model to simulate lifetime health outcomes of patients with type 2 diabetes mellitus using data from the 30 year United Kingdom Prospective Diabetes Study: UKPDS 82 Lipids in Diabetes Study. Diabetologia, 56, 1925-1933. http://doi.org/10.1007/s00125-0132940-y

Heinrich, E., Schaper, N. C., \& Vries, N. K. De. (2010). Self management interventions for type 2 diabetes: a systematic review. EDN Autumn, $7(2)$. 
Indonesia. (2014). Undang-Undang Nomor 24 Tahun 2011 tentang Badan Penyelenggara Jaminan Sosial. Kementerian Tenaga Kerja dan Transmigrasi, Republik Indonesia.

International Diabetes Federation. (2015) IDF Diabetes Atlas $7^{\text {th }}$ Edition 2015. https://www.idf.org/e-

library/epidemiology-

research/diabetes-atlas/13-diabetes-

atlas-seventh-edition.html

Kwon, S. K. (2014). Women are diagnosed with type 2 diabetes at higher body mass indices and older ages than men: Korea National Health and Nutrition Examination Survey. Diabetes and Metabolism Journal, $\quad 38, \quad$ 74-80. http://doi.org/10.4093/dmj.2014.38.1. $\underline{74}$

Mendez, A. B. V., Fittipaldi, J. A. S., Neves, R. C. S., Chacra, A. R., \& Moreira, E. D. (2010). Prevalence and correlates of inadequate glycaemic control: results from a nationwide survey in 6671 adults with diabetes in Brazil. Jounal Acta Diabetol, 47, 137-145.

http://doi.org/10.1007/s00592-0090138-z

Miguel-Yanes, D., Jose, M., Shrader, P., Pencina, M. J., Fox, C. S., Manning, A. K., ... Dupuis, J. (2011). Genetic risk reclassification for type 2 diabetes by age below or above 50 years using 40 type 2 diabetes risk single nucleotide polymorphism. Diabetes Care, 34, 121-125. http://doi.org/10.2337/dc10-1265

Muller, N., Heller, T., Freitag, M. H., Gerste, B., Haupt, C. M., Wolf, G., \& Muller, U. A. (2015). Healthcare utilization of people with type 2 diabetes in Germany: an analysis based on health insurance data. Journal Diabetic Medicine, 32, 951957.

http://doi.org/10.1111/dme.12747

Naidu, A. (2009). Factors affecting patient satisfaction and healthcare quality. International Journal of Health Care Quality Assurance, 22(4), 366-381. http://doi.org/10.1108/095268609109 64834

Nguyen, Q. M., Xu, J.-H., Chen, W., Srinivasan, S. R., \& Berenson, G. S. (2012). Correlates of Age Onset of Type 2 Diabetes Among Relatively Young Black and White Adults in a Community. Diabetes Care, 35, 1341-1346.

http://doi.org/10.2337/dc11-1818

Panagioti, M., Richardson, G., Small, N., Murray, E., Rogers, A., Kennedy, A., ... Bower, P. (2014). Self management support interventions to reduce health care utilisation without compromising outcomes: a systematic 
review and meta-analysis. Journal BMC Health Services Research, 14(356), $1-14$. http://doi.org/10.1186/1472-6963-14356

Perkeni. 2015. Konsensus Pengelolaan dan Pencegahan Diabetes melitus Tipe 2 di Indonesia 2015. ISBN: 978-97919388-6-0. Jakarta: PB Perkeni

Polonsky, W. H., Fisher, L., Hessler, D., \& Edelman, S. V. (2015). Development of a new measure for assessing glucose monitoring device related treatment satisfaction and quality of life. Diabetes Technology \& Therapeutics, 17(9), 657-663. http://doi.org/10.1089/dia.2014.0417

Riskesdas (2013). Riset Kesehatan Dasar RISKESDAS 2013. Jakarta: 2013

Roy, T., Lloyd, C. E., Pouwer, F., Holt, R. I. G., \& Sartorius, N. (2012). Screening tools used for measuring depression among people with type 1 and type 2 diabetes: a systematic review. Diabetes Medicine, 29, 164175. http://doi.org/10.1111/j.14645491.2011.03401.x

Scavini, M., Stidley, C. A., Shah, V. O., Narva, A. S., Tentorini, F., Kessler, D. S., .. Zager, P. G. (2003). Prevalence of diabetes is higher among female than male Zuni Indians. Diabetes Care, 26(1), 55-60.
Siminerio, L., Zgibor, J., \& Jr, F. X. S. (2004). Implementing the Chronic Care Model for Improvements in Diabetes Practice and Outcomes in Primary Care: The University of Pittsburgh Medical Center Experience, 22(2), 54-58.

Stellefson, M., Dipnarine, K., \& Stopka, C. (2013). The Chronic Care Model and Diabetes Management in US Primary Care Settings : A Systematic Review. Centers for Disease Control and Prevention, 10(1), 1-21. http://doi.org/10.5888/pcd10.120180 Tamayo, T., Brinks, R., Hoyer, A., Kub, O., \& Rathmann, W. (2016). The prevalence and incidence of diabetes in Germany. Deutsches Arzteblatt International, 113, 177-183. http://doi.org/10.3238/arztebl.2016.01 77

Wagner, E. H. (1998). Chronis Disease Management: What will it take to improve care forr chronic illness? Effective Clinical Practice, 1(1), 2-4. Yu, H., Xie, L. F., Chen, K., Yang, G. Y., Xing, X. Y., Zhao, J. J., ... Chen, B. (2016). Initiating characteristics of early-onset type 2 diabetes mellitus in chinese patients. Chinese Medical Journal, 129(7), 1-7. http://doi.org/10.4103/03666999.178959 